\title{
Experimental investigations of variations in petrophysical rock properties due to carbon dioxide flooding in oil heterogeneous low permeability carbonate reservoirs
}

\author{
Abdul Razag Y. Zekri • Shedid A. Shedid • \\ Reyadh A. Almehaideb
}

Received: 13 March 2013/ Accepted: 19 May 2013/Published online: 7 June 2013

(c) The Author(s) 2013. This article is published with open access at Springerlink.com

\begin{abstract}
Carbon dioxide has been successfully applied worldwide as an enhanced oil recovery process. Several important factors still have not been studied thoroughly. Therefore, this experimental study was carried out to investigate the variations in petrophysical reservoir rock properties of oil heterogeneous low permeability carbonate reservoirs. The main objectives of this experimental study are to investigate the effects of $\mathrm{CO}_{2}$ injection in tight limestone reservoir rocks on porosity, absolute and relative permeability, oil-water interfacial tension (IFT), reflective index, and reservoir water shielding phenomenon. Actual rock and fluid samples from an oil field in Abu Dhabi, UAE, are used to conduct this study at similar reservoir conditions of $4,000 \mathrm{psia}$ and $250^{\circ} \mathrm{F}$. Oil recovery, permeability, porosity, and relative permeability were measured before and after the supercritical carbon dioxide $\left(\mathrm{SC}-\mathrm{CO}_{2}\right)$ flood to examine the effects of SC- $\mathrm{CO}_{2}$ flood on the variation in different oil and rock properties of tight composite limestone reservoir rocks. Detailed compositional analysis of initial and produced oil samples of core flood experiments were analyzed using gas chromatography to assess the mechanism of $\mathrm{CO}_{2}$ improved oil recovery. The results indicated that the application of $\mathrm{SC}-\mathrm{CO}_{2}$ flooding under secondary and tertiary modes reduces porosity and permeability, alters relative permeability to a more waterwet condition, and reduces the oil/water IFT as a function of pore volume injected. Furthermore, the extracted
\end{abstract}

\footnotetext{
A. R. Y. Zekri · R. A. Almehaideb

UAE University, Al Ain,

United Arab Emirates

S. A. Shedid $(\bowtie)$

British University in Egypt (BUE),

El Sherouk, Egypt

e-mail: shedid.shedid@bue.edu.eg
}

components of the crude oil were also proven to be a function of injected $\mathrm{CO}_{2}$ pore volume. The applications of the attained results of this study provide much better understanding of different variation occurring in oil reservoirs under $\mathrm{SC}-\mathrm{CO}_{2}$ injection and can be used effectively to validate and improve numerical simulation studies.

Keywords Carbon dioxide - Carbonate reservoirs . Rock properties
Abbreviations
HCPV Hydrocarbon pore volume
GC Gas chromatography
$\mathrm{SC}-\mathrm{CO}_{2} \quad$ Supercritical carbon dioxide
WAG Water-alternating-gas

\section{Introduction and literature review}

Carbon dioxide $\left(\mathrm{CO}_{2}\right)$ injection has been widely used worldwide to enhance oil recovery of light-oil sandstone and carbonate reservoirs. Carbon dioxide may be applied as immiscible (injection pressure is less than minimum miscibility pressure (MMP) injection mode or as miscible mode (injection pressure is higher than MMP to develop a single phase of oil and injected gas), or supercritical carbon dioxide $\left(\mathrm{SC}-\mathrm{CO}_{2}\right.$, carbon dioxide is held at or above its critical temperature and critical pressure). For the $\mathrm{SC}-\mathrm{CO}_{2}$ injection to mobilize oil, it must have sufficient direct contact with that crude oil. Determination of oil distribution is necessary to study how the oil is contacted by the injected $\mathrm{CO}_{2}$. Oil is left in the reservoir after water flooding in three possible ways: (1) as droplets in pores surrounded by water, especially in water-wet rock; (2) in contact with 
the surface of the rock, typically in oil-wet rocks; and (3) a combination of the previous two conditions, called mixed wettability. Wettability conditions in the porous media may be estimated from fluid-flow behavior through the rock using wettability measurements.

Extensive laboratory work has been reported on the effects of water blocking during simultaneous water/solvent injection on the performance of miscible flooding (Raimondi and Tàrcaso 1946; Fitzgerald and Nielsen 1964; Stalkup 1970; Salter and Mohanty 1982; Tiffin and Yeilig 1983; Wang 1988; Lin and Huang 1990; Zekri et al. 2006). Previously published work concluded that at high water saturation, water blocking significantly affects the trapped volume of oil, but that oil trapping is insignificant after large pore volumes of injections (Salter and Mohanty 1982; Tiffin and Yeilig 1983; Wang 1988; Lin and Huang 1990; Zekri et al. 2006). Lin and Huang (1990) concluded that in water-wet cores, a significant amount of oil was trapped during simultaneous water/miscible solvent injection, due to the existence of mobile water saturation in the system. They (Lin and Huang 1990) also added that for oil-wet and mixed wettability systems, the amount of oil retained was insignificant. The previous finding was supported by Huang and Holm (1988) for the water-wet case. Ehrlich et al. (1984) reported a change of initially water-wet cores to nonwater-wet condition after injection of $\mathrm{CO}_{2}-$ Wateralternating-gas (WAG) to obtain residual oil saturation. This study also reported that the contact angle measurements supported the same conclusion of conversion the carbonate reservoir rock of Little Knife Field from waterwet to nonwater-wet wettability condition. It is clear that the wettability alteration is still an unsolved issue and may depend upon the nature and type of the reservoir rock, type and composition of reservoir fluids, and effects of $\mathrm{CO}_{2}$ interactions with rocks/fluids.

Shyeh-Yung (1991) stated that in tight water-wet limestone environment, water shielding is somewhat different from the water blocking phenomena in WAG floods. He indicated that oil extraction may not be an important oil recovery mechanism at high water saturations. Shyeh-Yung (1991) and Shedid et al. (2007) reported that secondary $\mathrm{CO}_{2}$ floods can recover more oil than tertiary floods. ShyehYung (1991) attributed the increase of oil recovery in secondary mode application to less water shielding.

\section{Effect of asphaltene deposition on the performance of $\mathrm{CO}_{2}$ flooding}

Monger and Fu (1987) conducted experimental investigation of reservoir parameters influencing organic deposition due to $\mathrm{CO}_{2}$ flooding. They showed that $\mathrm{CO}_{2}$-induced organic deposition resembles asphaltene precipitation by n-paraffins. The significant differences between the two processes are the deposition by $\mathrm{CO}_{2}$ is more extensive, less abrupt and associate with liquid-liquid phase equilibria, and it is not associated with the bubble point. They also concluded that regardless of initial wettability of Berea cores, the $\mathrm{CO}_{2}$-induced organic deposition changed the cores wettability to more oil-wet condition. Monger and Trujlllo (1991) provided analytical data sagging that asphaltene, resin, and waxes can precipitate in $\mathrm{CO}_{2}$-crude oil mixtures. They concluded that organic deposition was favored by the mass transfer that took place during miscibility development. Organic deposition was not observed after miscibility was reached, which implied less mass transfer took place at that point (Monger and Fu 1987). The study indicated that amount and composition of $\mathrm{CO}_{2}$-induced organic deposition were influenced by the presence of low molecular weight paraffins in the crude oil. Hagedorn and Orr (1994) showed that both molecular size and structure of crude oil affect the way molecules partitions into a $\mathrm{CO}_{2}$-rich gas phase. Multiring aromatic components in crude oils are more difficult to extract by dense $\mathrm{CO}_{2}$ than other hydrocarbon components of similar size (Hagedorn and Orr 1994). Huang (1992) investigated the effects of oil composition and asphaltene content on $\mathrm{CO}_{2}$ displacement. He concluded that oil recovery efficiency decreased if the C5-C19 fraction in the oil decreased or the asphaltene content increased. He (Huang 1992) also reported that when asphaltene content in the crude oil exceeds $4.6 \mathrm{wt} \%$, the wettability of Berea sandstone cores would change from water-wet to oil-wet and that would produce lower oil recovery.

Negahban et al. (2003) evaluated the asphaltene instability during hydrocarbon gas or $\mathrm{CO}_{2}$ flooding using a crude oil from a field in Abu Dhabi, UAE. They indicated that asphaltenes were stable in the reservoir fluids at the reservoir temperature, but the addition of hydrocarbon gas instigated asphaltene precipitation. However, addition of $\mathrm{CO}_{2}$ did not affect the stability of asphaltene. They also concluded that even though asphaltene precipitated during hydrocarbon floods, it did not produce a plugging problem due to the fact that the asphaltene particle size was much less than the size of the pore throat. (Takahashi et al. 2003) reported no significant permeability reduction was observed even though large amount of asphaltene was left behind in the carbonate core after $\mathrm{CO}_{2}$ injection. This study also concluded that a large amount of asphaltene was left behind in the carbonate core after $\mathrm{CO}_{2}$ flooding and no significant permeability reduction due to asphaltene precipitation was observed. This finding contradicted Wolcott et al. (1989) finding who believed that rock mineralogy controlled the site of asphaltene deposition.

Gholoum et al. (2003) studied the effect of different alkanes $\left(\mathrm{C}_{1}-\mathrm{C}_{7}\right)$ and $\mathrm{CO}_{2}$ on the onset of asphaltene precipitance of Kuwaiti reservoirs fluid samples and revealed 
that $\mathrm{CO}_{2}$ was the most effective asphaltene precipitant followed by alkanes $\left(\mathrm{C}_{1}-\mathrm{C}_{7}\right)$. This showed that the asphaltenes deposition depends on the oil composition and its interaction with $\mathrm{CO}_{2}$ (Srivastava et al. 1997) reported that asphaltene precipitation and/or adsorption depended on the permeability of the core matrix tested. They (Srivastava et al. 1997) investigated asphaltene deposition during $\mathrm{CO}_{2}$ flooding. They reported that the most important factor for asphaltene deposition is the $\mathrm{CO}_{2}$ concentration and pore topography. The high-grain-size vuggy matrix showed the highest asphaltene precipitation during $\mathrm{CO}_{2}$ injection. A minimum effect of brine saturation on asphaltene flocculation was observed. However, increasing brine concentration inhibited the asphaltene flocculation (Srivastava and Huang 1997). Bon and Sarma (2004) observed no asphaltene problems during mixing of $\mathrm{CO}_{2}$ and crude oil obtained from Cooper Basin Oilfield, Australia. Although, this crude oil contained $0.1 \mathrm{wt} \%$ asphaltene, Bon and Sarma (2004) believed that high resin of the crude is the reason behind asphaltene stability in the presence of $\mathrm{CO}_{2}$.

Al-Maamari and Buckley (2000) observed a significant increase in oil-wet conditions close to the onset of asphaltene precipitation for four of five studied oils indicating the possibility of change in system wettability at conditions of asphaltene instability. Potter (1987) used intermediate oil-wet, intermediate wettability, and intermediate water-wet dolomite cores obtained from West Texas formation to study the effect of $\mathrm{CO}_{2}$ flood on wettability. The results showed that the cores became slightly more water-wet.

Chemical kinetics of SC- $\mathrm{CO}_{2}$ flooding is an important concept that needs to be studied. Reactions between reservoir oil, brine, formation rock, and $\mathrm{CO}_{2}$ most probably will lead to changes in the formation permeability, pore size distribution, and the effective porosity. Changes in rock porosity and permeability result from either dissolution of rock minerals and/or asphaltene precipitation. While dissolution of rock minerals might increase the permeability and effective porosity, precipitation of asphaltene and the deposition of dissolved minerals lead to an opposite effect. Omole and Osoba (1983) studied the interaction between $\mathrm{CO}_{2}$ and dolomite rock during $\mathrm{CO}_{2}$ flooding process and reported an increase in dolomite permeability by $3.5-5 \%$, while reduction in permeability was observed for some other experiments. Those results lead someone to believe that the process depends on the distribution of the rock minerals. Izgec et al. (2005) employed computerized tomography (CT) laboratory experiments to monitor $\mathrm{CO}_{2}$ injection experiments in aquifers. They observed an increase in permeability initially then a decrease for low injection rate cases. At low salt concentration, the decrease in porosity and permeability was less pronounced, which indicated that salt precipitation might contribute to the plugging process. This study also indicated that permeability reduction occurred due to two different mechanisms: (1) accumulation of small particles of asphaltenes in larger pore throat causing a continuous reduction in the pore throat area open to flow, and (2) large size asphaltene blocks the small pore throat. Those results lead to the belief that the process depends on the distribution of the rock minerals. Izgec et al. (2005) also observed an increase of the $\mathrm{pH}$ of the effluent water in many instances and explained that $\mathrm{CO}_{2}$ did not move freely to the end of the core plug and formed carbonic acid only at the inlet. The $\mathrm{CO}_{2}$ would preferably be in the hydrocarbon phase than the aqueous phase and its solubility in water is very limited. Stern (1991) observed that extraction does not play an important role as an oil recovery mechanism in mixed wettability and water-wet cores for WAG floods. Small amounts of oil-water emulsions were observed in effluents from $\mathrm{CO}_{2}$ floods in this work. These emulsions could be generated by the presence of carbonic acid resulting from the dissolution of $\mathrm{CO}_{2}$ in water, which acts as a weak emulsifying agent. Holm and Josendal (1984) concluded that the range of hydrocarbon components extracted by $\mathrm{CO}_{2}$ were the C5-C12, while Huang (1992) reported a wider oil component range extracted by $\mathrm{CO}_{2}$, i.e., $\mathrm{C} 5$ through $\mathrm{C} 19$.

The refractive index (RI) is used in this study as previously employed by other researchers (Buckley 1997, 1999; Buckley et al. 1998) to estimate the onset of asphaltene precipitation as a function of pore volume injection and to verify that asphaltene does precipitate and in this study RI at the onset of precipitation is denoted by PRI. At RI values above PRI, asphaltenes remain dispersed, and below it they flocculate and precipitate.

Distribution of fluids and flow behavior of crude oil, $\mathrm{CO}_{2}$, and brine are controlled mainly by interfacial interactions between these fluids and reservoir rock during $\mathrm{CO}_{2}$ floods. These interfacial interactions include the wettability, capillary pressure, dispersion, and interfacial tension (IFT). Under certain conditions of pressure and temperature, capillary pressure, wettability and dispersion can be closely related to IFT (Craig 1971; Dullien 1992; Yang 1994; Adamson 1996; Firoozabadi 1999).

Searching the literature revealed that no work has been done previously made on the effect of $\mathrm{CO}_{2}$ on IFT between oil and water and actual measurements of porosity and permeability prior to and post $\mathrm{CO}_{2}$ flooding of asphaltenic crude oil in composite low permeability reservoir rocks. In addition, very limited work was conducted on $\mathrm{SC}-\mathrm{CO}_{2}$ of carbonate water-wet rocks. Although the literature is vast on wettability alteration and the effect of different brine concentrations on the $\mathrm{CO}_{2}$ flooding process, there is a real need for more research and analysis on this subject. This motivated the authors of this work to design and conduct this study to investigate the impact of water shielding and $\mathrm{CO}_{2}$ flooding on porosity and permeability, wettability, and 
possible alteration of IFT between oil and water. The study also investigates the performance of $\mathrm{SC}-\mathrm{CO}_{2}$ flooding in actual composite cores extracted from carbonate oil field under different water saturation conditions.

\section{Material and apparatus}

This study used actual light crude oil of $31.67^{\circ}$ API with low asphaltene content of $0.20 \mathrm{wt} \%$ from an actual oil field in Abu Dhabi, UAE. The history of this oil field has shown no prior experience of asphaltene precipitation. The $\mathrm{CO}_{2}$ injection is expected to acuse changes in the $\mathrm{pH}$, which may lead to the destabilization of asphaltene held in the crude oil. Asphaltene precipitation may cause wettability alteration and permeability reduction. Therefore, an evaluation of porosity, permeability, and relative permeability prior and post the $\mathrm{CO}_{2}$ injection was performed in this study to evaluate possible variations in reservoir petrophysical rock properties.

\section{Fluids}

The oil used in this study is obtained from Well A of an oilfield in Abu Dhabi, UAE. The physical properties of this oil are listed in Table 1. Gas chromatography-mass spectrometry, a Varian 3800 unit was used in this study to fraction the oil to different groups. These groups were compared against known standard to identify crude oil groups, ethane, propane, and other components. The oil has a kinematic viscosity of $6.3 \mathrm{cSt}$ at $40{ }^{\circ} \mathrm{C}$, and has a low content of asphaltene of $0.2 \mathrm{wt} \%$. Figure 1 presents the results of compositional analysis of the used crude oil. The oil has a slightly low content of C6-C8 cuts and high content of the n-C9 to $\mathrm{n}-\mathrm{C} 20$ cuts. The brine employed in this project is collected at surface conditions from Well B located in the same field. Table 2 presents the compositional analysis of the used brine.

Table 1 Properties of crude oil

\begin{tabular}{lll}
\hline Property & Value & ASTM method \\
\hline $\begin{array}{l}\text { Specific gravity } \\
\text { at } 20{ }^{\circ} \mathrm{C}\end{array}$ & 0.8672 & $\mathrm{D} 287$ \\
$\begin{array}{l}\text { API gravity at } \\
15{ }^{\circ} \mathrm{C}\end{array}$ & $31.67^{\circ}$ & $\mathrm{D} 287$ \\
$\begin{array}{l}\text { Kinematic } \\
\text { viscosity at }\end{array}$ & $6.3 \mathrm{cSt}$ & $\mathrm{D} 445$ \\
$\begin{array}{l}4{ }^{\circ} \mathrm{C} \\
\begin{array}{l}\text { Total acid } \\
\text { number }\end{array}\end{array}$ & $0.9537 \mathrm{mg} \mathrm{KOH} / \mathrm{g}$ oil & $\mathrm{D} 974$ \\
$\begin{array}{l}\text { Asphaltene } \\
\text { content }\end{array}$ & $0.20 \%$ & $\mathrm{D} 6560$ \\
\hline
\end{tabular}

Core flood apparatus

A schematic diagram of the supercritical flooding (SCF) experimental apparatus used in this study is shown in Fig. 2. The experimental apparatus consisted of a $260-\mathrm{ml}$ capacity syringe pump (ISCO 260-Series D) of different constant flow rates and a controller system, an oven and stainless steel core holder. The $\mathrm{CO}_{2}$ was compressed to $4,200 \mathrm{psi}$ pressure and injected as every volume of $39.4 \mathrm{ml}$ SC- $\mathrm{CO}_{2}$ displaces $0.7 \mathrm{~cm}^{3}$ of oil and water contained in the core sample. The core holder is placed horizontally in a variable temperature oven. Pressure and temperature transducers are connected to both ends of the core inside the core holder. A chart recorder and a digital pressure recorder are connected to temperature and pressure transducers, respectively.

Experimental procedure

Porosity, permeability, and fluid saturation determination

Four core stacks (3.8-cm diameter and $6.65-\mathrm{cm}$ length) were used to prepare three core composite samples. These cores are called in this study as core 1 , core 2 , and core 3 , respectively. These composite cores were used to investigate the effect of $\mathrm{SC}-\mathrm{CO}_{2}$ on petrophysical properties of tight composite limestone reservoirs. Each composite core consisted of four individual core stacks that were arranged in descending order of permeability with respect to the flow direction. The used limestone cores to get these stacks were dried at $80{ }^{\circ} \mathrm{C}$ for $72 \mathrm{~h}$ after cleaning and before cutting each core into small plugs. Each core was cleaned by injecting five pore volumes of Toluene through it. The core was then flushed with ten pore volumes of actual brine. Each core was evacuated for $12 \mathrm{~h}$ and saturated with filtrated actual formation brine. During this step, we measured the volume of brine required to fully saturate the core to determine its pore volume. Then, effective rock porosity was calculated volumetrically. The rocks were then flooded with actual crude oil till irreducible water saturation was attained. The volumes of residual brine and oil were used with rock pore volume to calculate the fluid saturations. When a steady-state flow condition of oil was established, variation of pressure drop along the core was used with other rock and flow parameters to calculate the rock permeability using Darcy's Law. At this stage, cores were cut into smaller stacks and used to get composite cores. Each composite core was directly flooded with formation water to reach conditions of 30 and $50 \%$ of residual oil saturation, respectively. Table 3 presents the results of measured porosity and permeability for the three different composite cores (core 1, core 2, and core 3) used in this study. 
Fig. 1 Original oil compositional analysis

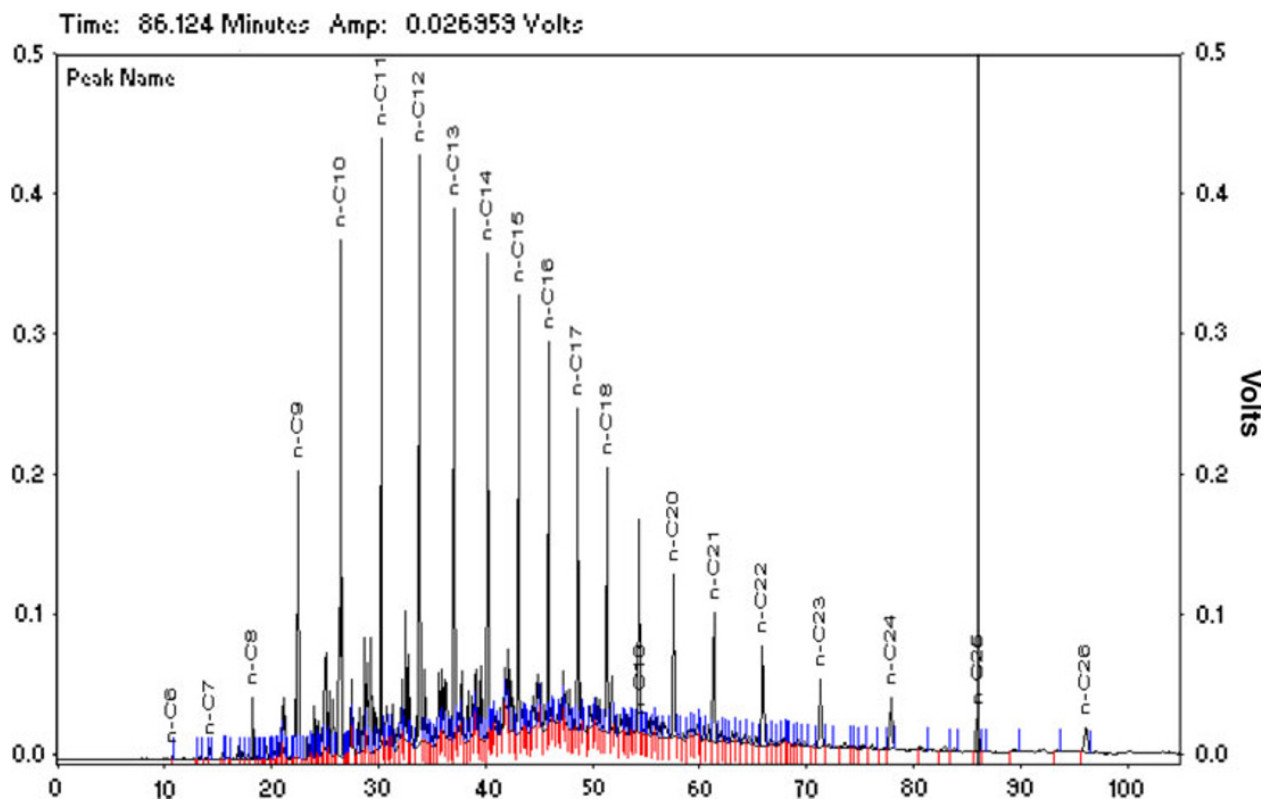

Table 2 Composition of formation water

\begin{tabular}{lrlr}
\hline Cations $(\mathrm{ppm})$ & \multicolumn{3}{c}{ Anions $(\mathrm{ppm})$} \\
\hline Sodium & 54,000 & Chloride & 155,000 \\
Calcium & 15,000 & Bromide & 850 \\
Magnesium & 1,791 & Sulfate & 993 \\
Strontium & 880 & Phosphate & 90 \\
Potassium & 1,275 & & \\
\hline
\end{tabular}

To assure continuity, a tissue paper was placed between each of two adjacent core stacks in the composite.

Two other tight limestone cores (called core 4 and core 5) were obtained from another well in the same field and used to study the effect of $\mathrm{SC}-\mathrm{CO}_{2}$ floods on the relative permeability. Core 4 has brine permeability of $0.63 \mathrm{md}$ and porosity of $29 \%$, while core 5 has brine permeability of $0.81 \mathrm{md}$ and effective porosity of $36 \%$. The cores were prepared as described previously and fully saturated with oil at irreducible water saturation (Swir). Water flooding of these cores was conducted at a constant pressure, and oil and water production were measured continuously as function of time until the water-oil ratio (WOR) reached about $100 \%$. Cores were then re-flooded with oil to establish a residual water saturation state followed by $\mathrm{CO}_{2}$ flooding at $4,000 \mathrm{psia}$ and $250{ }^{\circ} \mathrm{F}$. Once the cores were fully saturated with $\mathrm{SC}-\mathrm{CO}_{2}$ at irreducible oil saturation, the $\mathrm{CO}_{2}$ injection stopped and water injection was initiated to completely saturate the core with water at residual oil saturation. Cores were then flooded with oil to prepare them for the post $\mathrm{SC}-\mathrm{CO}_{2}$ flood relative permeability measurements. Results indicated that the used cores in this phase of the work are water-wet cores. Produced oil and water interfacial tensions were measured as a function of pore volume injected (PVI). It is well known that changes in rock wettability and in IFT between oil and water can significantly affect the displacement process. The IFT between produced oil and brine was measured in this study using Spinning Drop Interfacial Tensiometer of Model 500, which was manufactured by Corexport Corporation in USA.
Fig. 2 Supercritical (SC) $-\mathrm{CO}_{2}$ flooding system

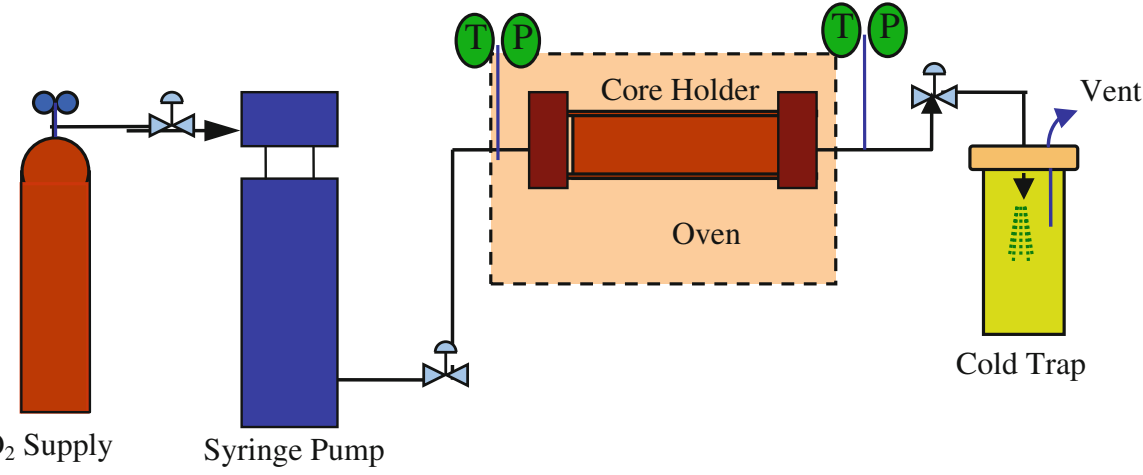

$\mathrm{CO}_{2}$ Supply $\quad$ Syringe Pump 
Table 3 Properties of three composite cores

\begin{tabular}{|c|c|c|c|c|c|}
\hline \multicolumn{2}{|c|}{ Core 1 , So $=79 \%$} & \multicolumn{2}{|c|}{ Core 2, So $=30 \%$} & \multicolumn{2}{|c|}{ Core 3 , So $=50 \%$} \\
\hline $\begin{array}{l}\text { Porosity } \\
(\Phi) \%\end{array}$ & $\begin{array}{l}\text { Permeability } \\
(k), \text { Md }\end{array}$ & $\begin{array}{l}\text { Porosity } \\
(\Phi) \%\end{array}$ & $\begin{array}{l}\text { Permeability } \\
(k), \mathrm{Md}\end{array}$ & $\begin{array}{l}\text { Porosity } \\
(\Phi), \%\end{array}$ & $\begin{array}{l}\text { Permeability } \\
(k), \mathrm{Md}\end{array}$ \\
\hline 18.31 & 0.45 & 24.69 & 4.51 & 23.45 & 4.5066 \\
\hline 18.63 & 0.07 & 17.35 & 2.02 & 17.35 & 0.0038 \\
\hline 27.80 & 0.01 & 18.00 & 0.84 & 13.73 & 0.0136 \\
\hline 14.42 & 0.003 & 13.73 & 0.74 & 3.73 & 0.0135 \\
\hline
\end{tabular}

\section{Supercritical $\mathrm{CO}_{2}$ flooding}

All core flooding experiments were performed at $250{ }^{\circ} \mathrm{F}$ and 4,000 psia to ensure miscibility conditions [minimum miscibility pressure (MMP) of 1,237 was measured using slim tube and calculated using different empirical correlations to be of average of 3,730 psi]. Cores were prepared to specific condition of oil saturation (So $=79 \%$, So $=50 \%$, and So $=30 \%$ ) as described in the previous section. After preparing the cores to the specified oil saturation, $\mathrm{SC}-\mathrm{CO}_{2}$ injection was initiated. A constant $\mathrm{CO}_{2}$ volume equivalent to $0.15 \mathrm{HCPV}$ (Hydrocarbon Pore Volume) was injected and followed by water flooding for all runs studying the effect of water saturation. This slug was optimized in separate studies, which were published in references (Shedid et al. 2005, 2007). A backpressure regulator was placed at the outlet of the system to depressurize the produced fluids from 3,900 psia to atmospheric pressure. The produced oil and water were collected in $20 \mathrm{~cm}^{3}$ tubes and the displaced gas was passed through a Ruska Gasometer to measure the total produced volumes. The displaced fluid was collected in small volumes of almost $3-4 \mathrm{~cm}^{3}$ to study the changes in the crude oil composition as function of PVI.

\section{Results and discussion}

Effects of water shielding on performance of $\mathrm{SC}-\mathrm{CO}_{2}$ flooding

It is well known that there is a difference in oil recovery between slim tube and core flooding experiments, although both are conducted under the same pressures and temperatures. The slim tube contains no water and has a highly permeable bead pack. The presence of water in core floods is one possible reason for the observed difference in $\mathrm{CO}_{2}$ performance between slim tube and core flooding experiments. The presence of water may make oil less accessible to $\mathrm{CO}_{2}$ and most of the injected $\mathrm{CO}_{2}$ interacts with the water. To our knowledge, the effects of water shielding on the performance of $\mathrm{SC}-\mathrm{CO}_{2}$ injection as a miscible process in tight limestone rocks has not been investigated before. Therefore, different core flooding experiments were conducted using composite cores to investigate the effect of water shielding on the performance of SC- $\mathrm{CO}_{2}$ flooding. SC- $\mathrm{CO}_{2}$ was injected in different composite cores having oil saturations of 30, 50, and $79 \%$ with a descending order of permeability, as shown in Table 3. The studied systems were classified as secondary flood (at So $=79 \%$ ), intermediate flood (at So $=50 \%$ ), and tertiary flood (at So $=30 \%$ ). All runs were conducted at $250{ }^{\circ} \mathrm{F}$ and 4,000 psia, a condition adopted in this work to ensure that the $\mathrm{CO}_{2}$ is at supercritical conditions and miscible with the employed oil.

Results from these experiments of secondary, intermediate, and tertiary floods showed that more oil recovery could be obtained if the flooding process was started at higher mobile oil saturation, as shown in Fig. 3. The oil recovery from miscible $\mathrm{CO}_{2}$ flooding dropped from $91 \%$ for secondary flood to $73 \%$ for tertiary flood of original oil in place (OOIP), as shown in Fig. 4. Results indicated that oil recovery after 1.2 pore volumes injected (PVI) of $\mathrm{CO}_{2}$ in a tertiary flood was almost the same as after 0.375 and 0.395 PVI of $\mathrm{CO}_{2}$ in an intermediate and secondary floods, respectively. It took almost similar PVI in all three cases to recover the oil. Figure 4 presents the oil recovery versus initial oil saturation for the studied systems. These results, therefore, supports the conclusion that the presence of a water phase hinders the performance of $\mathrm{CO}_{2}$ floods for tight carbonate reservoirs. This behavior could be explained as follows: more oil could be contacted in a secondary flood; oil can be extracted much easier in the secondary mode of $\mathrm{CO}_{2}$ flooding and extracted components can form a middle phase with less losses to the water phase. For this study, more water shields oil from contacting $\mathrm{CO}_{2}$ occurred in the presence of different water saturations. It also has a significant effect on the displacement of oil by $\mathrm{SC}-\mathrm{CO}_{2}$ and the resultant miscible flood overall oil recovery.

Produced oil composition

Oil produced from the secondary, intermediate, and tertiary $\mathrm{CO}_{2}$ floods was analyzed by gas chromatography (GC). The vent/sample gathering GC conditions are atmospheric pressure of $14.7 \mathrm{psia}$ and temperature of $25^{\circ} \mathrm{C}$. Due to the limitation of the chromatography column, only crude oil 


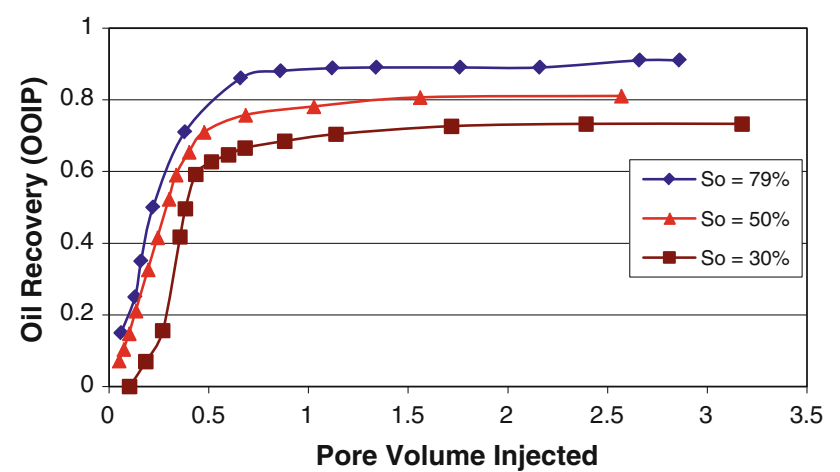

Fig. 3 Oil recovery versus PVI

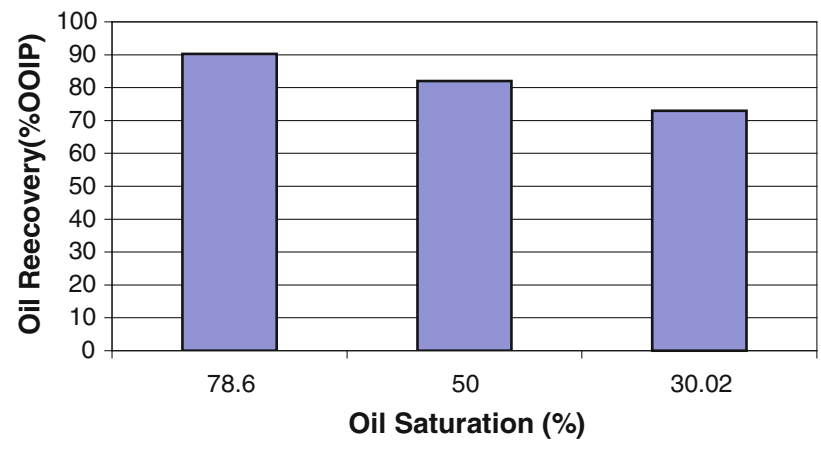

Fig. 4 Oil recovery versus oil saturation

components from $\mathrm{n}-\mathrm{C}_{6}$ to $\mathrm{n}-\mathrm{C}_{26}$ could be detected and quantified. Produced oil compositions were evaluated by comparing them to the original oil composition used in this study. The injected oil was stock tank oil obtained from Well A.

Tables 4, 5, and 6 present the compositions of original oil, the composition of the effluent oil cuts from the three composite core floods, and the normalized oil compositions, respectively. The normalized compositions are calculated by dividing weight $\%$ of each component at any oil cut by the corresponding weight $\%$ from the original oil. Normalized compositions above one indicate that the component is preferentially extracted. If no extraction is performed on that specific component, its normalized concentration should be 1.0 or $<1.0$. Table 4 presents the data for the normalized produced oil composition as a function of PVI for the secondary flood at So $=79 \%$. The data indicated that components lighter that $\mathrm{n}-\mathrm{C}_{12}$ increased with their normalized composition above 1 at $0.4 \mathrm{PVI}$ injected, which means that $\mathrm{CO}_{2}$ did not extract the components heavier than $\mathrm{n}-\mathrm{C}_{11}$ at that PVI. During the period between 0.8 to $1.6 \mathrm{PVI}$, normalized compositions for components lighter than $n-C_{13}$ remained very close to one. This indicated that $\mathrm{CO}_{2}$ extracted $\mathrm{n}-\mathrm{C}_{6}$ to $\mathrm{n}-\mathrm{C}_{13}$ during $\mathrm{SC}-\mathrm{CO}_{2}$ secondary flood process of $\mathrm{So}=79 \%$ of the composite core. The composition behavior of the $\mathrm{CO}_{2}$ displaced oil during intermediate flood of So $=50 \%$ are presented in Table 5. Data indicated that components from $\mathrm{n}-\mathrm{C}_{7}$ to $\mathrm{n}-\mathrm{C}_{9}$ were extracted at $0.05 \mathrm{PVI}$ injected. Table 5 further indicated that all the components were extracted at some point during the flooding process of the composite core. This indicated that the $\mathrm{CO}_{2}$ concentration $\left(\mathrm{CO}_{2} /\right.$ oil ratio) played a role in the extraction process and the intermediate case was an ideal condition for $\mathrm{CO}_{2}$ to extract the crude oil. Therefore, a wider range of components was extracted during intermediate $\mathrm{SC}-\mathrm{CO}_{2}$ flood.

Similar behavior of the normalized oil composition as a function of PVI were observed in the case of tertiary SC$\mathrm{CO}_{2}$ flood when compared to an intermediate $\mathrm{SC}-\mathrm{CO}_{2}$ flood, as shown in Table 6. The same conclusion can be drawn in the case of intermediate $\mathrm{SC}-\mathrm{CO}_{2}$ flood regarding extracted oil components. The authors of this study believe that the range of components being extracted by $\mathrm{CO}_{2}$ is a function of oil composition and $\mathrm{CO}_{2}$ concentration as indicated by the results of this work.

Asphaltene precipitation and its effects on the concentration of oil is another factor that has to be considered in evaluating oil composition variation as a function of PVI. This factor could be eliminated by de-asphalting the crude oil and re-running all the experiments and this situation does not exist in the field for this crude. Therefore, our conclusion regarding extracted components is a preliminary one and further work is needed to come up with a definite conclusion on this mechanism.

\section{Effect of SC- $\mathrm{CO}_{2}$ floods on permeability and porosity}

Figures 5 and 6 showed the measured permeability before and after $\mathrm{CO}_{2}$ flooding as a function of distance from the inlet for the secondary and tertiary floods, respectively. Figure 5 indicated improvement of the permeability along the composite core in the case of the secondary flood, while Fig. 6 showed in general a permeability reduction along the composite core in the case of the tertiary flood. Those results lead to the belief that the process depends on the distribution of the rock minerals. Figure 6 showed the permeability measurements along the composite core as function of distance from the core inlet for the tertiary flood system. No change in permeability was observed at a short distance from the inlet and that was because the improvement in permeability due to the dissolution of carbonate rocks by $\mathrm{CO}_{2}$ dissolved in water was masked by the damage effect of asphaltene precipitation. The probable reason is that in the case of tertiary floods flooding, the $\mathrm{CO}_{2}$ contacts more water and, as a result, dissolves in that water forming carbonic acid, which dissolves the calcite and counteracts any permeability reduction due to asphaltene precipitation in this core and at downstream fine migration and deposition, contributed significantly to the observed damage. For a carbonate system, the kinetics of 
Table 4 Oil and normalized oil composition, So $=79 \%$

\begin{tabular}{|c|c|c|c|c|c|c|c|c|c|c|c|}
\hline \multirow[t]{2}{*}{ Components } & \multirow{2}{*}{$\begin{array}{l}\text { OPVI } \\
\text { Crude oil }\end{array}$} & \multicolumn{2}{|l|}{0.4 PVI } & \multicolumn{2}{|l|}{0.8 PVI } & \multicolumn{2}{|l|}{ 1.1 PVI } & \multicolumn{2}{|c|}{ 1.6 PVI } & \multicolumn{2}{|l|}{$2.1 \mathrm{PVI}$} \\
\hline & & Comp. & N. Comp. & Comp. & N. Comp. & Comp. & N. Comp. & Comp. & N. Comp. & Comp. & N. Comp. \\
\hline n-C6 & 0.028 & 0.359 & 12.821 & 0.000 & 0.000 & 0.000 & 0.000 & 0.051 & 1.821 & 0.027 & 0.964 \\
\hline $\mathrm{n}-\mathrm{C} 7$ & 0.158 & 1.909 & 12.082 & 0.452 & 2.861 & 0.550 & 3.481 & 0.285 & 1.804 & 0.574 & 3.633 \\
\hline $\mathrm{n}-\mathrm{C} 8$ & 0.808 & 6.061 & 7.501 & 1.374 & 1.700 & 0.092 & 0.114 & 1.357 & 1.679 & 1.919 & 2.375 \\
\hline $\mathrm{n}-\mathrm{C} 9$ & 4.963 & 9.293 & 1.872 & 4.863 & 0.980 & 3.405 & 0.686 & 4.620 & 0.931 & 11.816 & 2.381 \\
\hline $\mathrm{n}-\mathrm{C} 10$ & 9.968 & 14.059 & 1.410 & 11.905 & 1.194 & 19.841 & 1.990 & 10.680 & 1.071 & 26.870 & 2.696 \\
\hline $\mathrm{n}-\mathrm{C} 11$ & 9.782 & 10.173 & 1.040 & 10.999 & 1.124 & 23.124 & 2.364 & 9.375 & 0.958 & 20.557 & 2.102 \\
\hline $\mathrm{n}-\mathrm{C} 12$ & 10.327 & 0.407 & 0.039 & 12.045 & 1.166 & 20.626 & 1.997 & 9.597 & 0.929 & 14.880 & 1.441 \\
\hline $\mathrm{n}-\mathrm{C} 13$ & 8.447 & 7.841 & 0.928 & 9.272 & 1.098 & 11.808 & 1.398 & 8.669 & 1.026 & 7.400 & 0.876 \\
\hline $\mathrm{n}-\mathrm{C} 14$ & 7.703 & 6.778 & 0.880 & 7.004 & 0.909 & 6.785 & 0.881 & 7.171 & 0.931 & 3.458 & 0.449 \\
\hline $\mathrm{n}-\mathrm{C} 15$ & 6.947 & 6.440 & 0.927 & 6.490 & 0.934 & 3.440 & 0.495 & 6.907 & 0.994 & 1.454 & 0.209 \\
\hline $\mathrm{n}-\mathrm{C} 16$ & 5.859 & 5.392 & 0.920 & 5.301 & 0.905 & 2.088 & 0.356 & 5.827 & 0.995 & 0.537 & 0.092 \\
\hline $\mathrm{n}-\mathrm{C} 17$ & 5.886 & 4.998 & 0.849 & 4.837 & 0.822 & 1.366 & 0.232 & 5.481 & 0.931 & 1.068 & 0.181 \\
\hline $\mathrm{n}-\mathrm{C} 18$ & 5.015 & 4.658 & 0.929 & 4.390 & 0.875 & 1.075 & 0.214 & 5.109 & 1.019 & 7.382 & 1.472 \\
\hline n-C19 & 4.484 & 4.014 & 0.895 & 4.186 & 0.934 & 0.066 & 0.015 & 4.526 & 1.009 & 0.128 & 0.029 \\
\hline $\mathrm{n}-\mathrm{C} 20$ & 4.353 & 3.759 & 0.864 & 3.562 & 0.818 & 0.459 & 0.105 & 4.206 & 0.966 & 0.102 & 0.023 \\
\hline $\mathrm{n}-\mathrm{C} 21$ & 3.622 & 3.396 & 0.938 & 3.188 & 0.880 & 0.334 & 0.092 & 3.783 & 1.044 & 0.374 & 0.103 \\
\hline $\mathrm{n}-\mathrm{C} 22$ & 3.409 & 3.170 & 0.930 & 3.029 & 0.889 & 0.028 & 0.008 & 3.603 & 1.057 & 0.131 & 0.038 \\
\hline $\mathrm{n}-\mathrm{C} 23$ & 2.626 & 2.325 & 0.885 & 2.248 & 0.856 & 4.829 & 1.839 & 2.824 & 1.075 & 0.897 & 0.342 \\
\hline $\mathrm{n}-\mathrm{C} 24$ & 2.258 & 1.963 & 0.869 & 1.899 & 0.841 & 0.010 & 0.004 & 2.306 & 1.021 & 0.070 & 0.031 \\
\hline $\mathrm{n}-\mathrm{C} 25$ & 1.73 & 1.578 & 0.912 & 1.523 & 0.880 & 0.059 & 0.034 & 1.884 & 1.089 & 0.212 & 0.123 \\
\hline $\mathrm{n}-\mathrm{C} 26$ & 1.626 & 1.427 & 0.878 & 1.433 & 0.881 & 0.015 & 0.009 & 1.739 & 1.069 & 0.144 & 0.089 \\
\hline
\end{tabular}

Table 5 Oil and normalized produced oil composition, So $=50 \%$

\begin{tabular}{|c|c|c|c|c|c|c|c|c|c|}
\hline \multirow[t]{2}{*}{ Components } & \multirow{2}{*}{$\begin{array}{l}\text { Crude oil } \\
\text { Comp. }\end{array}$} & \multicolumn{2}{|c|}{ PVI: 0.05} & \multicolumn{2}{|c|}{ PVI: 0.19} & \multicolumn{2}{|c|}{ PVI: 0.4} & \multicolumn{2}{|c|}{ PVI: 2.1} \\
\hline & & Comp. & N. Comp. & Comp. & N. Comp. & Comp. & N. Comp. & Comp. & N. Comp. \\
\hline n-C6 & 0.028 & 0.000 & 0.000 & 0.000 & 0.000 & 0.000 & 0.000 & 0.000 & 0.000 \\
\hline $\mathrm{n}-\mathrm{C} 7$ & 0.158 & 0.134 & 0.848 & 0.148 & 0.937 & 0.065 & 0.411 & 0.000 & 0.000 \\
\hline $\mathrm{n}-\mathrm{C} 8$ & 0.808 & 1.151 & 1.425 & 1.200 & 1.485 & 0.883 & 1.093 & 0.300 & 0.371 \\
\hline $\mathrm{n}-\mathrm{C} 9$ & 4.963 & 4.865 & 0.980 & 4.638 & 0.935 & 4.400 & 0.887 & 2.319 & 0.467 \\
\hline $\mathrm{n}-\mathrm{ClO}$ & 9.968 & 7.314 & 0.734 & 6.639 & 0.666 & 7.241 & 0.726 & 4.556 & 0.457 \\
\hline $\mathrm{n}-\mathrm{C} 11$ & 9.782 & 10.085 & 1.031 & 9.479 & 0.969 & 10.829 & 1.107 & 7.906 & 0.808 \\
\hline $\mathrm{n}-\mathrm{C} 12$ & 10.327 & 9.607 & 0.930 & 9.345 & 0.905 & 10.897 & 1.055 & 8.681 & 0.841 \\
\hline $\mathrm{n}-\mathrm{C} 13$ & 8.447 & 8.531 & 1.010 & 8.500 & 1.006 & 9.912 & 1.173 & 8.471 & 1.003 \\
\hline $\mathrm{n}-\mathrm{C} 14$ & 7.703 & 7.553 & 0.981 & 7.599 & 0.986 & 8.668 & 1.125 & 8.014 & 1.040 \\
\hline $\mathrm{n}-\mathrm{C} 15$ & 6.947 & 7.032 & 1.012 & 7.162 & 1.031 & 7.923 & 1.140 & 7.931 & 1.142 \\
\hline $\mathrm{n}-\mathrm{C} 16$ & 5.859 & 6.125 & 1.045 & 6.261 & 1.069 & 6.565 & 1.120 & 7.172 & 1.224 \\
\hline $\mathrm{n}-\mathrm{C} 17$ & 5.886 & 5.816 & 0.988 & 5.929 & 1.007 & 6.053 & 1.028 & 6.896 & 1.172 \\
\hline $\mathrm{n}-\mathrm{C} 18$ & 5.015 & 5.436 & 1.084 & 5.588 & 1.114 & 5.406 & 1.078 & 6.541 & 1.304 \\
\hline $\mathrm{n}-\mathrm{C} 19$ & 4.484 & 4.545 & 1.014 & 4.694 & 1.047 & 4.272 & 0.953 & 5.512 & 1.229 \\
\hline $\mathrm{n}-\mathrm{C} 20$ & 4.353 & 4.223 & 0.970 & 4.414 & 1.014 & 3.675 & 0.844 & 5.202 & 1.195 \\
\hline $\mathrm{n}-\mathrm{C} 21$ & 3.622 & 3.915 & 1.081 & 4.141 & 1.143 & 3.230 & 0.892 & 4.800 & 1.325 \\
\hline $\mathrm{n}-\mathrm{C} 22$ & 3.409 & 3.770 & 1.106 & 3.996 & 1.172 & 2.944 & 0.864 & 4.573 & 1.341 \\
\hline $\mathrm{n}-\mathrm{C} 23$ & 2.626 & 2.708 & 1.031 & 2.981 & 1.135 & 2.090 & 0.796 & 3.577 & 1.362 \\
\hline $\mathrm{n}-\mathrm{C} 24$ & 2.258 & 3.513 & 1.556 & 3.238 & 1.434 & 2.436 & 1.079 & 2.930 & 1.298 \\
\hline $\mathrm{n}-\mathrm{C} 25$ & 1.73 & 1.904 & 1.101 & 2.076 & 1.200 & 1.307 & 0.755 & 2.404 & 1.390 \\
\hline $\mathrm{n}-\mathrm{C} 26$ & 1.626 & 1.772 & 1.090 & 1.974 & 1.214 & 1.206 & 0.742 & 2.216 & 1.363 \\
\hline
\end{tabular}


Table 6 Oil and normalized produced oil composition, So $=30 \%$

\begin{tabular}{|c|c|c|c|c|c|c|c|c|c|}
\hline \multirow[t]{2}{*}{ Components } & \multirow{2}{*}{$\begin{array}{l}\text { Crude oil } \\
\text { Comp. }\end{array}$} & \multicolumn{2}{|c|}{0.269 PVI } & \multicolumn{2}{|c|}{$0.51 \mathrm{PVI}$} & \multicolumn{2}{|c|}{0.88 PVI } & \multicolumn{2}{|c|}{ 2.19 PVI } \\
\hline & & Camp. & N. Com p. & Comp. & N. Comp. & Comp. & N. Comp. & Camp, & N. Comp. \\
\hline n-C6 & 0.028 & $0 . C 39$ & 1.393 & 0.000 & 0.000 & 0.000 & 0.000 & 0.000 & 0.000 \\
\hline $\mathrm{n}-\mathrm{C} 7$ & 0.158 & 0.310 & 1.963 & 0.232 & 1.468 & 0.024 & 0.152 & 0.048 & 0.304 \\
\hline $\mathrm{n}-\mathrm{C} 8$ & 0.808 & 1.486 & 1.838 & 1.477 & 1.828 & 0.452 & 0.553 & 0.578 & 0.715 \\
\hline $\mathrm{n}-\mathrm{C} 9$ & 4.963 & 4.598 & 0.926 & 4.750 & 0.957 & 2.758 & 0.556 & 3.057 & 0.616 \\
\hline $\mathrm{n}-\mathrm{C} 10$ & 9.968 & 10.222 & 1.025 & 10.730 & 0.376 & 8.039 & 0.806 & 8.403 & 0.773 \\
\hline $\mathrm{n}-\mathrm{C} 11$ & 9.782 & 9.093 & 0.930 & 9.591 & 0.980 & 8.258 & 0.844 & 8.423 & 0.361 \\
\hline $\mathrm{n}-\mathrm{C} 12$ & 10.327 & 8.432 & 0.817 & 8.898 & 0.862 & 8.261 & 0.800 & 8.409 & 0.314 \\
\hline $\mathrm{n}-\mathrm{C} 13$ & 8.447 & 8.393 & 0.994 & 8.777 & 1.039 & 8.543 & 1.011 & 8.692 & 1.029 \\
\hline $\mathrm{n}-\mathrm{C} 14$ & 7.703 & 7.615 & 0.989 & 7.330 & 1.016 & 7.913 & 1.027 & 8.003 & 1.039 \\
\hline $\mathrm{n}-\mathrm{C} 15$ & 6.947 & 7.401 & 1.035 & 7.496 & 1.079 & 7.790 & 1.121 & 7.860 & 1.131 \\
\hline $\mathrm{n}-\mathrm{C} 16$ & 5.859 & 6.062 & 1.035 & 5.107 & 1.042 & 6.509 & 1.111 & 6.617 & 1.129 \\
\hline $\mathrm{n}-\mathrm{C} 17$ & 5.886 & 5.781 & 0.982 & 5.622 & 0.955 & 6.218 & 1.056 & 6.308 & 1.072 \\
\hline $\mathrm{n}-\mathrm{C} 18$ & 5.015 & 5.356 & 1.070 & 5.230 & 1.043 & 6.324 & 1.261 & 5.322 & 1.161 \\
\hline $\mathrm{n}-\mathrm{C} 19$ & 4.484 & 4.686 & 1.045 & 4.518 & 1.008 & 5.542 & 1.236 & 5.152 & 1.149 \\
\hline $\mathrm{n}-\mathrm{C} 20$ & 4.353 & 4.266 & 0.980 & 4.047 & 0.930 & 4.991 & 1.147 & 4.695 & 1.079 \\
\hline $\mathrm{n}-\mathrm{C} 21$ & 3.622 & 4.011 & 1.107 & 3.712 & 1.025 & 4.625 & 1.277 & 4.405 & 1.216 \\
\hline n- C22 & 3.409 & 3.634 & 1.066 & 3.309 & 0.971 & 4.158 & 1.220 & 3.976 & 1.166 \\
\hline $\mathrm{n}-\mathrm{C} 23$ & 2.626 & 2.687 & 1.023 & 2.447 & 0.932 & 3.092 & 1.177 & 3.090 & 1.177 \\
\hline $\mathrm{n}-\mathrm{C} 24$ & 2.258 & 2.264 & 1.003 & 2.100 & 0.930 & 2.583 & 1.144 & 2.545 & 1.127 \\
\hline $\mathrm{n}-\mathrm{C} 25$ & 1.73 & 1.878 & 1.085 & 1.639 & 0.947 & 2.043 & 1.181 & 2.049 & 1.184 \\
\hline $\mathrm{n}-\mathrm{C} 26$ & 1.626 & 1.778 & 1.093 & 1.488 & 0.915 & 1.879 & 1.156 & 1.868 & 1.149 \\
\hline
\end{tabular}

reaction between $\mathrm{CO}_{2}$ and formation water is as follows (Omole and Osoba 1983):

$$
\mathrm{H}_{2} \mathrm{O}+\mathrm{CO}_{2}+\mathrm{CaCO}_{3} \leftrightarrow \mathrm{Ca}\left(\mathrm{HCO}_{3}\right)_{2}
$$

The solution of $\mathrm{CO}_{2}$ in water and the formation of a weak acidic solution were confirmed by measuring the $\mathrm{pH}$ of produced water. Figure 6 showed also an extensive damage at a distance of around $10.03 \mathrm{~cm}$ from the inlet. It is more likely because at that point miscibility started to take place, i.e., mass transfer between the $\mathrm{CO}_{2}$ and the oil, which corresponds to asphaltene precipitation. Another possible reason is the change from high permeability

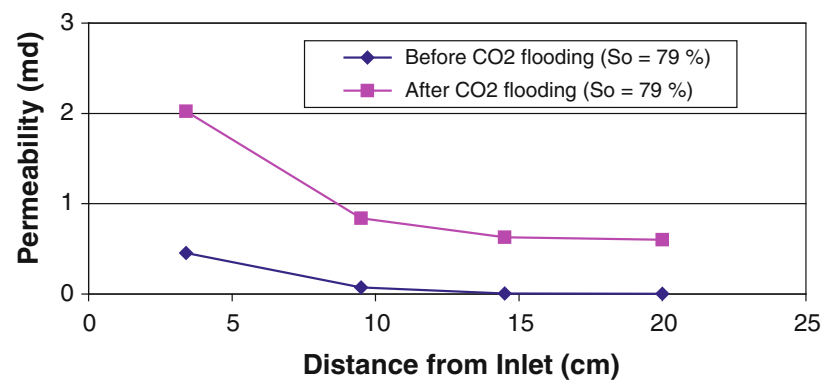

Fig. 5 Permeability versus distance from inlet (at So $=79 \%$ )

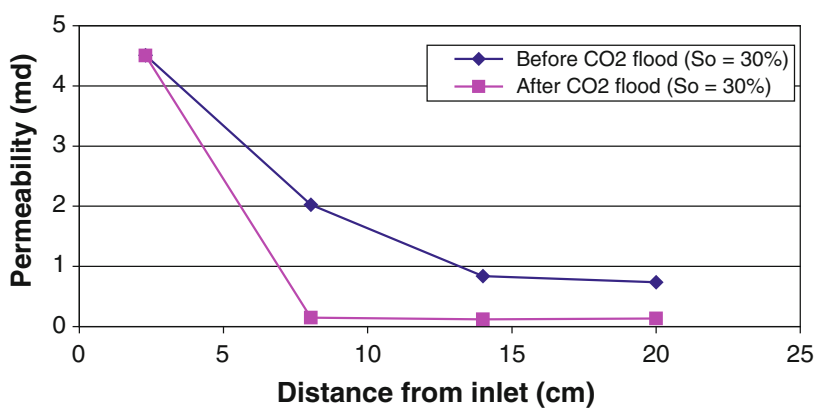

Fig. 6 Permeability versus distance from inlet (at So $=30 \%$ )

values at inlet to low permeability zone at the outlet as we move along the composite core.

Figure 7 showed the change of the $\mathrm{pH}$ of produced water as function of PVI for both secondary and intermediate $\mathrm{SC}-\mathrm{CO}_{2}$ floods. As observed in Fig. 7, the $\mathrm{pH}$ of the produced water changed during the flooding process and became more acidic. As expected, the change of the $\mathrm{pH}$ of the produced water, for the intermediate flood, took place very quickly during the flooding process compared to the secondary flood. In the case of the intermediate flood, the $\mathrm{CO}_{2}$ can easily contact formation water as compared to a secondary flood. The produced water $\mathrm{pH}$ dropped from 6.4 to 5.6 after less than one PVI for the intermediate flood 


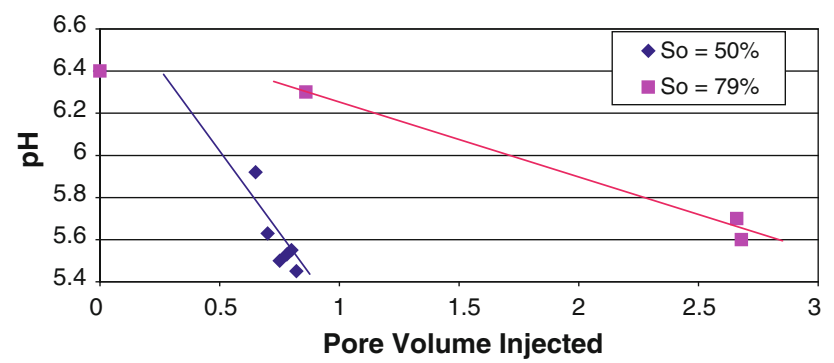

Fig. 7 Produced water $\mathrm{pH}$ versus PVI

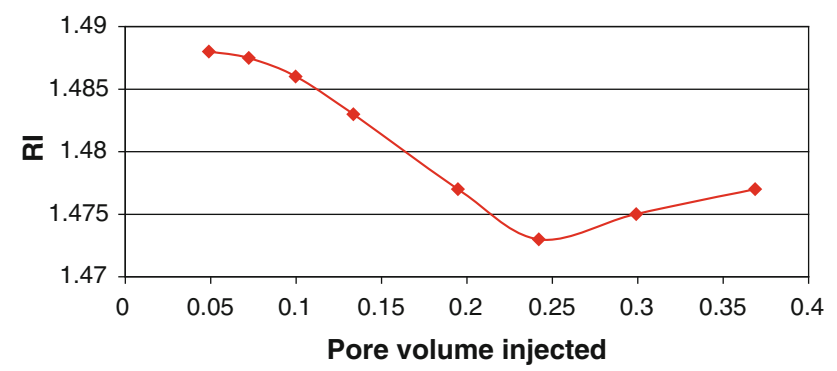

Fig. 8 Refractive index of produced oil versus PVI

compared with a pH drop from 6.4 to 5.6 after 2.68 PVI for the secondary flood.

The RI values for produced oil cut were measured as a function of PVI for the intermediate $\mathrm{SC}-\mathrm{CO}_{2}$ flood, Fig. 8. The onset of asphaltene precipitation took place after 0.2 pore volumes were injected for the studied system.

The effects of $\mathrm{SC}-\mathrm{CO}_{2}$ floods on porosity measurements along the composite core prior to and after $\mathrm{CO}_{2}$ injection for the secondary and tertiary supercritical floods were displayed in Figs. 9 and 10, respectively. In this case, similar trends were observed in both cases of secondary and tertiary moods. On the average, around $7.5 \%$ reduction of composite core porosity was observed in both studied cases as a result of SC$\mathrm{CO}_{2}$ flooding. This may be attributed to asphaltene precipitation and deposition of dissolved calcium carbonates.

Effect of SC- $\mathrm{CO}_{2}$ floods on relative permeability

Oil-water relative permeability prior and after $\mathrm{SC}-\mathrm{CO}_{2}$ floods were measured for two tight cores obtained from the selected oil field. Water wettability were inferred from connate water saturation, the saturation at which oil and water relative permeabilities are equal, and the relative permeability at residual oil saturation, as explained by Craig (1971). Figures. 11 and 12 showed the relative permeability curves for experiments 4 and 5 , respectively, prior to $\mathrm{CO}_{2}$ flooding. The relative permeability data clearly indicates that both cores used in these experiments are water-wet cores as demonstrated by the location of crossover point above $50 \%$ water saturation in the both cases. The sudden increase in water relative permeability

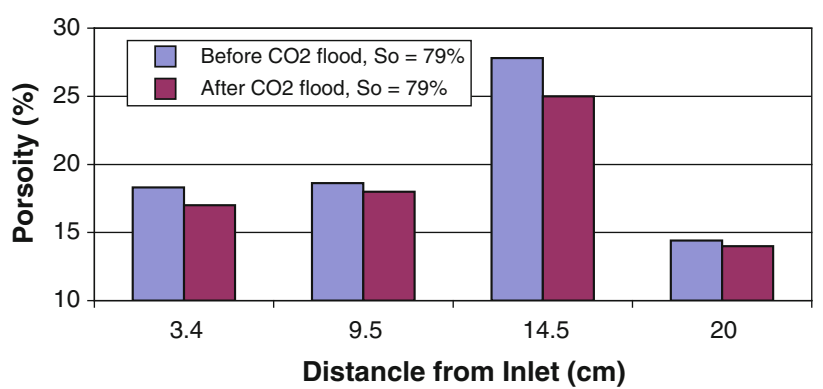

Fig. 9 Porosity versus distance from inlet (secondary flood)

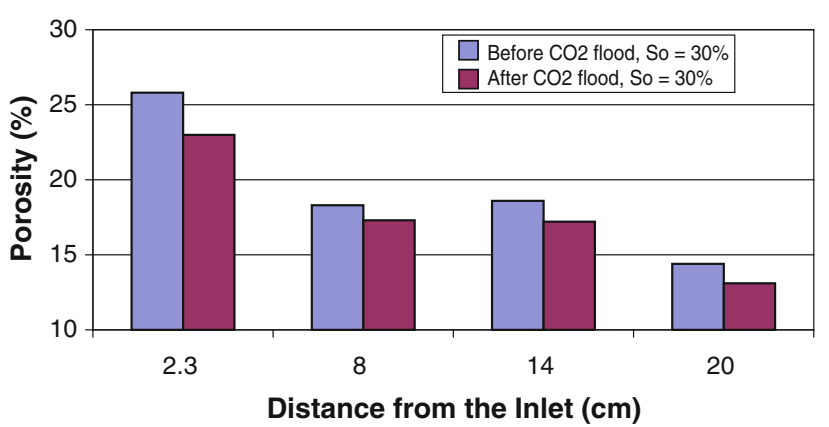

Fig. 10 Porosity versus distance from inlet (tertiary flood)

in Figs. 11 and 12 can be attributed to severe heterogeneity of carbonate rocks and more accumulation of water in high permeability sections of composite cores.

Figures 13 and 14 presented the relative permeabilities curves for experiments 4 and 5, respectively, after $\mathrm{SC}-\mathrm{CO}_{2}$ flooding. The characteristics of both curves indicated that the cores became more water-wet, which is favorable for the flow of oil. The results attained by our current study matched the results by Potter (1987), who used water-wet cores obtained from a West Texas dolomite formation to study the effect of $\mathrm{CO}_{2}$ flooding on the reservoir wettability. His results confirmed that the cores became slightly more waterwet. Alteration of rocks wettability to more water-wet will result in favorable oil displacement efficiency.

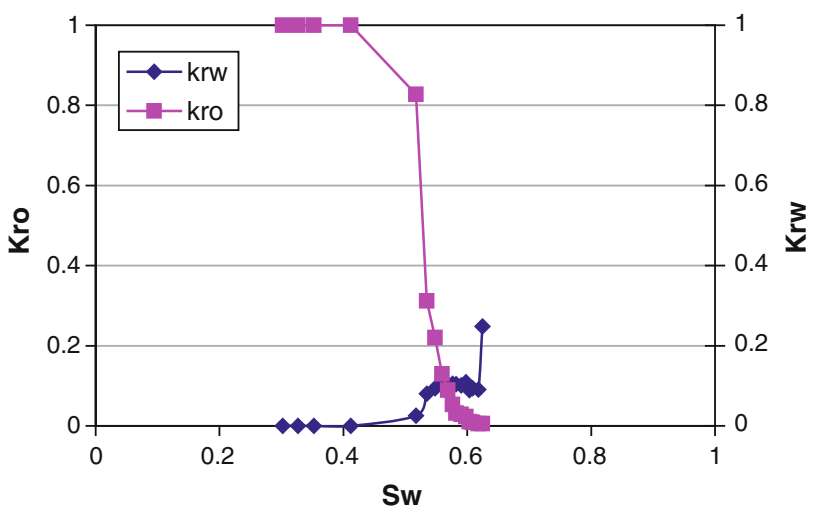

Fig. 11 Oil-water relative permeability prior to $\mathrm{CO}_{2}$ flood (core 4) 


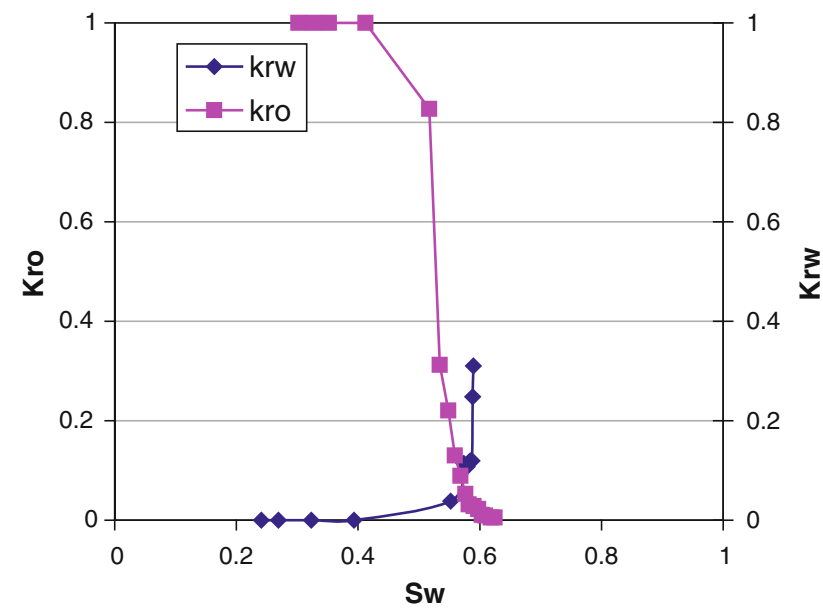

Fig. 12 Oil-water relative permeability prior to $\mathrm{CO}_{2}$ flood (core 5)

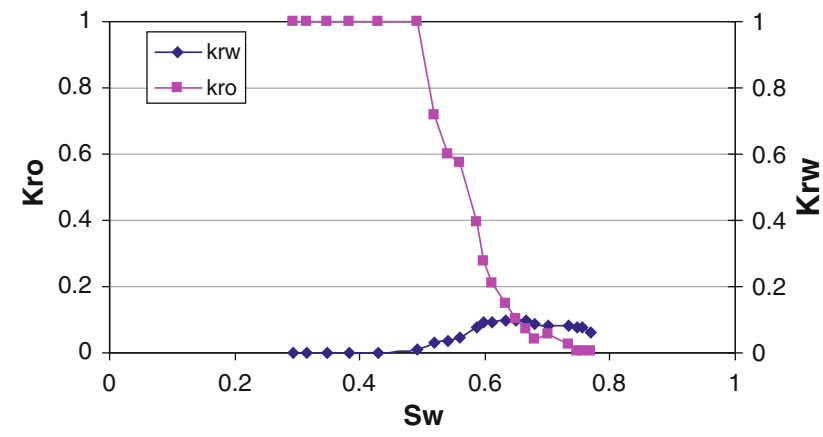

Fig. 13 Oil-water relative permeability after $\mathrm{CO}_{2}$ flood (core 4)

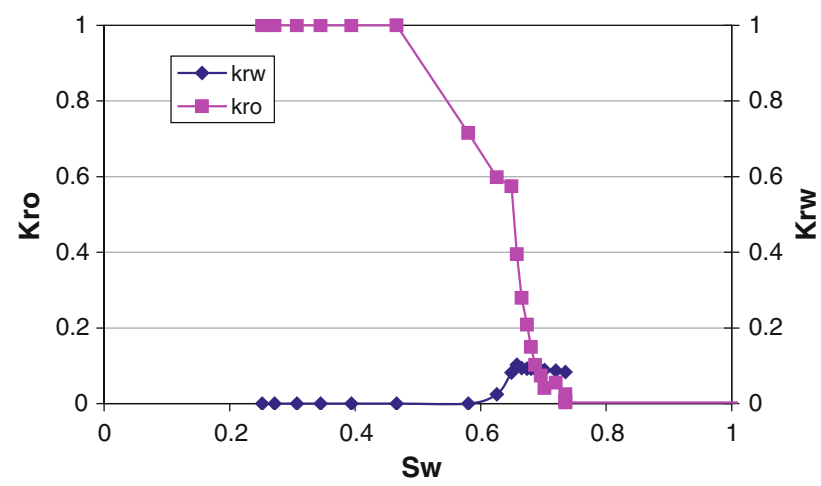

Fig. 14 Oil-water relative permeability after $\mathrm{CO}_{2}$ flood (Core 5)

Making the cores more water-wet reduces the oil residual saturation and increases the irreducible water saturation as observed when comparing $\mathrm{CO}_{2}$ floods relative permeability plots before and after flooding. In addition, an improvement in the ratio of the effective oil permeability to the effective water permeability at any given water saturation is manifested in both cases which results in a favorable water fractional flow curves after $\mathrm{CO}_{2}$ flood as shown in Figs. 15 and 16.

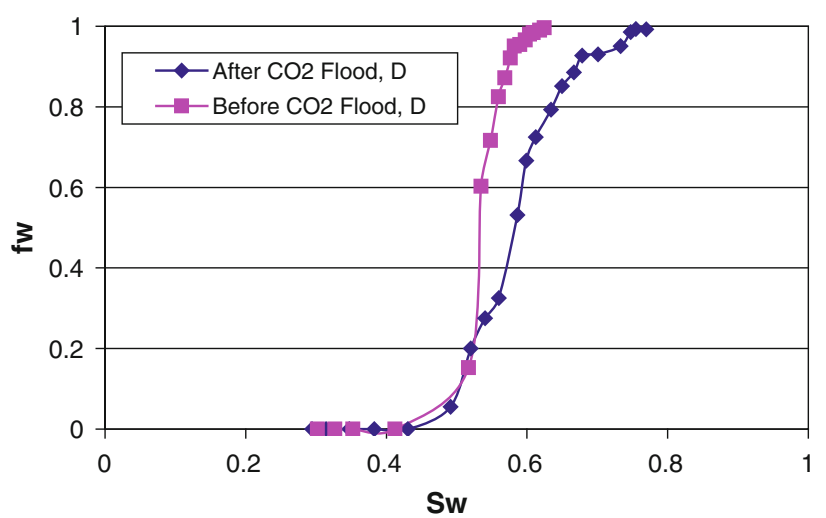

Fig. 15 Fractional flow of water curves of experiment 4

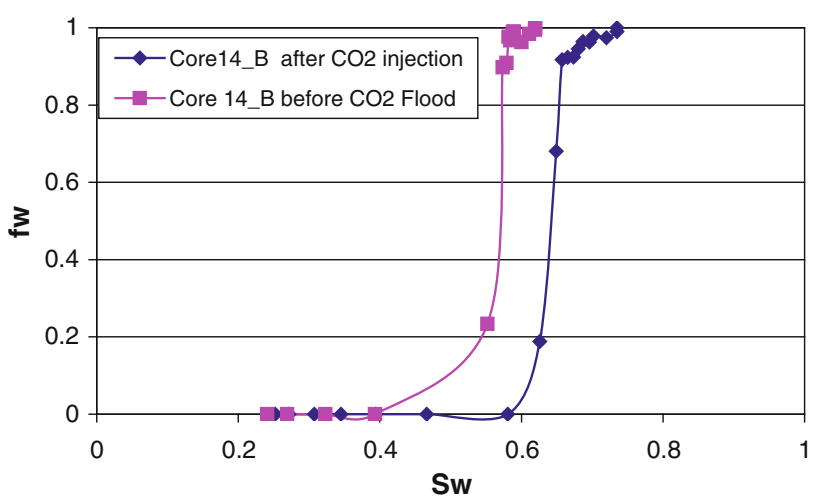

Fig. 16 Fractional flow of water curves of experiment 5

Effect of SC-CO2 on the water/oil interfacial tension (IFT)

In this work, the effect of $\mathrm{SC}-\mathrm{CO}_{2}$ on the IFT between the employed crude oil and brine after exposure to $\mathrm{SC}-\mathrm{CO}_{2}$ was studied using the spinning drop model 500 interfacial tensiometer. Measurements were made at an atmospheric pressure of 15 psia and room temperature of $65^{\circ} \mathrm{F}$ conditions for all effluent oil cuts. Figure 17 showed that the IFT between produced crude oil and produced brine as a function of PVI for experiment 4 using core 4 . The high value of IFT $=65 \mathrm{dyne} / \mathrm{cm}$ may be attributed to the presence of asphaltene in the crude oil. All measurements were made three times and average value was reported. A maximum drop of IFT of $85 \%$ was observed after 0.25 pore volume was injected. This PVI is very close to the PVI at which the lowest RI was observed, as shown in Fig. 8. It is clearly demonstrated that $\mathrm{SC}-\mathrm{CO}_{2}$ altered the IFT between the crude oil and its brine to a favorable condition. Reduction of IFT is expected to improve the fractional flow of oil as demonstrated in Figs. 15 and 16 and to reduce the residual oil saturation by the reduction of capillary forces. 


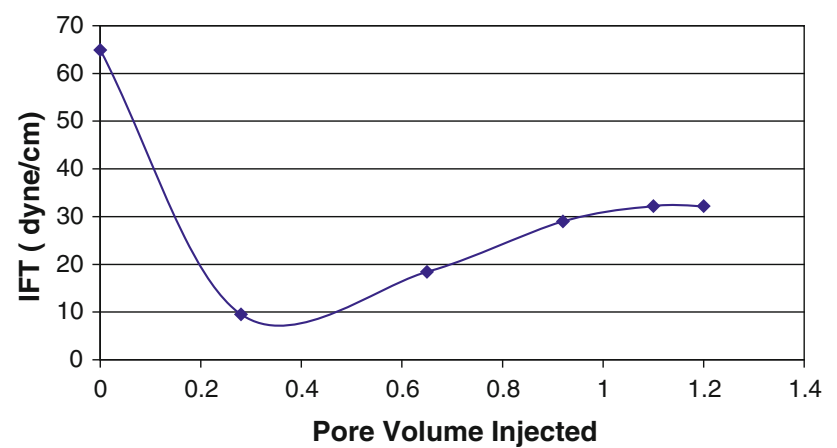

Fig. 17 Oil-water interfacial tension versus PVI (experiment 4)

\section{Conclusions}

This experimental study was undertaken to study the influences of $\mathrm{SC}-\mathrm{CO}_{2}$ flooding on petrophysical rock properties of asphaltenic oil flowing through composite rocks. Based on the results of this study, the following conclusions can be drawn:

1. The application of $\mathrm{SC}-\mathrm{CO}_{2}$ flooding at early stage of oil recovery as a secondary and/or intermediate mode(s) results in higher oil recovery than its application as a tertiary mode. This is attributed to the presence of more mobile water phase during the late injection of $\mathrm{SC}-\mathrm{CO}_{2}$.

2. Compositional analysis of produced oil from $\mathrm{SC}-\mathrm{CO}_{2}$ applications at different initial oil saturations indicated that the application of $\mathrm{SC}-\mathrm{CO}_{2}$ flooding for waterflooded or partially water-flooded reservoirs is recommended when oil extraction mechanism is more valid as a recovery mechanism.

3. The extracted components of reservoir oil in composite reservoirs by $\mathrm{SC}-\mathrm{CO}_{2}$ are function of $\mathrm{CO}_{2}$ PVI.

4. The $\mathrm{SC}-\mathrm{CO}_{2}$ flooding of composite cores extracts heavier components of oil at higher water saturation and lighter components of oil at higher mobile oil saturations.

5. The $\mathrm{SC}-\mathrm{CO}_{2}$ flood of composite cores caused reduction in porosity for both secondary and tertiary applied modes, while permeability was improved when $\mathrm{CO}_{2}$ was applied as a tertiary recovery mode due to the dissolution effect of carbonate rocks.

6. The injection of $\mathrm{SC}-\mathrm{CO}_{2}$ flood in tight composite carbonate oil reservoirs changed the wettability to be a favorable condition of more water-wet.

7. The recovery mechanisms of $\mathrm{SC}-\mathrm{CO}_{2}$ flooding are identified to be due to fractional extraction of some oil components and reduction in oil-water IFT.

Acknowledgments This work is conducted as part of a research contract between UAE University and Occidental Petroleum, Abu Dhabi, UAE on "Possible Use of CO2 in Miscible Flooding of UAE
Reservoirs". The authors would like to thank both Oxy-Abu Dhabi and the Abu Dhabi National Oil Company (ADNOC) for their support and provision of field information and data contained in this report. The authors would also like to thank the UAEU Research Sector for the opportunity to conduct this research.

Open Access This article is distributed under the terms of the Creative Commons Attribution License which permits any use, distribution, and reproduction in any medium, provided the original author(s) and the source are credited.

\section{References}

Adamson AW (1996) Physical chemistry of surfaces, the 6th Cd. John Wiley \& Sons Inc., New York

Al-Maamari R, Buckley J (2000) Aspahltene precipitation and alteration of wetting: can wettability change during oil production? In: SPE 59292, the SPE/DOE improved oil recovery symposium, Tulsa, Oklahoma, 3-5 April 2000

Bon J, Sarma HK (2004) A technical evaluation of a $\mathrm{CO}_{2}$ flood for EOR benefits in the Cooper Basin, South Australia. In: SPE 88451, the SPE Asia Pacific oil and gas conference and exhibition, Australia, 18-20 Oct. 2004

Buckley JS (1999) "Predicting the onset of asphaltene precipitation from refractive index measurements. Energy Fuels 13(2): 328-332

Buckley JS, Liu Y, Xie X, Morrow NR (1997) “Asphaltenes and crude oil wetting-the effect of oil composition," SPEJ. 107-119

Buckley JS, Hirasaki GJ, Liu Y, Von Drasek S, Wang JX, Gill BS (1998) Asphaltene precipitation and solvent properties of crude oils. J Petroleum Sci Technol 16(3-4):251-285

Craig FF (1971) "The reservoir engineering aspects of waterflooding", monograph Series. SPE Monogr 3:20-21

Dullien FAL (1992) "Media: fluid transport and pore structure", 2nd edn. Academic Press, New York

Ehrlich R, Tracht J, Kaye S (1984) "Laboratory and field study of the effect of mobile water on $\mathrm{CO}_{2}$-flood residual oil saturation". JPT 1797-1809

Firoozabadi A (1999) Thermodynamics of hydrocarbon reservoirs. McGraw-Hill Inc., New York

Fitzgerald JO, Nielsen RF (1964) "Oil recovery from a consolidated core by light hydrocarbons in the presence of high water saturations". In: Mineral industrial experimental station circular No. 66, Pennsylvania State U., University Park, p 1711964

Gholoum EF, Oskui GP, Salman M (2003) "Investigation of aspahltene precipitation onset conditions for Kuwaiti reservoirs". In: SPE 81571 , the middle east oil show and conference, Bahrain, 5-8 April 2003

Hagedorn KD, Orr FM (1994) Components partitioning in $\mathrm{CO}_{2} /$ crude oil systems: effects of oil composition on $\mathrm{CO}_{2}$ displacement performance. SPE Adv Technol Ser 2(2):177-184

Holm LW, Josendal VA (1984) "Study shows best use of $\mathrm{CO}_{2}$ as EOR Agent". Oil Gas J 131-134

Huang ES (1992) "The effect of oil composition and asphaltene content on $\mathrm{Co}_{2}$ displacement". In: SPE 24131, the SPE/DOE symposium on enhanced oil recovery, Tulsa, Oklahoma pp 22-24

Huang E, Holm LW (1988) "Effect of WAG injection and rock wettability on oil recovery during $\mathrm{CO}_{2}$ flooding". J SPE Reserv Eng 119-129

Izgec O, Demiral B, Bertin $\mathrm{H}$, Akin S (2005) " $\mathrm{CO}_{2}$ injection in carbonates". In: SPE 93773, The 2005 SPE western regional meeting, Irvine, CA., 30 Mar-1 Apr 
Lin EC, Huang TS (1990) "The effect of rock wettability on water blocking during miscible displacement”. J SPE Reserv Eng 205-212

Monger TG, Fu JC (1987) "The nature of $\mathrm{CO}_{2}$-induced organic deposition". In: SPE 16713, the SPE annual technical conference and exhibition, Dallas, 27-30

Monger TG, Trujlllo DE (1991) "Organic deposition during $\mathrm{CO}_{2}$ and rich-gas flooding". SPE Reserv Eng 17-24

Negahban S, Joshi N, Jamaluddin AK, Nighswander J (2003) "A systematic approach for experimental study of asphaltene deposition for an Abu Dhabi reservoir under WAG Development Plan". In: SPE 80261, the SPE Oilfield Chemistry Symposium, Houston, 5-7 Feb. 2003

Omole O, Osoba JS (1983) " $\mathrm{CO}_{2}$-dolomite rock I interaction during $\mathrm{CO}_{2}$ flooding process". In: the 34th annual meeting of the petroleum society of CIM, Canada 1983

Potter GF (1987) "The effects of $\mathrm{CO}_{2}$ flooding on wettability of West Texas dolomite formations". In: SPE 16716, the 62nd SPE annual conference and exhibition, Dallas, 27-30 Sept. 1987

Raimondi P, Tàrcaso MA (1946) Distribution of the oil phase obtained upon imbibitions of water. Trans AIME SPEJ 49-55:231-239

Salter SJ, Mohanty KK (1982) "Multiphase flow in porous media: I. macroscopic observations and modeling". In: SPE 11017, the SPE annual technical conference and exhibition, New Orleans, Louisiana, 26-29 Sept. 1982

Shedid SA, Zekri AY, Almehaideb R (2005) "Microscopic rock characterization and influence of slug size on oil recovery by $\mathrm{CO}_{2}$ miscible flooding in carbonate oil reservoir". In: SPE 97635, the international improved oil recovery conference in Asia Pacific, Kuala Lumpur, Malaysia, 5-6 Dec 2005

Shedid SA, Zekri AY, Almehaideb R (2007) "Laboratory investigation of influences of initial oil saturation and oil viscosity on oil recovery by $\mathrm{CO}_{2}$ miscible flooding". In: SPE 106958, EUROPEC/EAGE conference and exhibition, London, UK, 11-14 June 2007

Shyeh-Yung, J-G J (1991) "Mechanisms of miscible oil recovery: effects of pressure on miscible and near-miscible displacements of oil by carbon dioxide". In: SPE 22651, the 66th annual technical conference and exhibition, Dallas, 6-9 Oct. 1991

Srivastava RK, Huang SS (1997) "Asphaltene deposition during $\mathrm{CO}_{2}$ flooding: a laboratory assessment”. In: SPE 37468, the SPE production operation symposium, Oklahoma, 9-11 March 1997

Stalkup FI (1970) Displacement of oil by solvent at high water saturation. SPE J 10(4):337-348

Stern D (1991) "Mechanism of miscible oil recovery: effects of porelevel fluid distributions". Paper SPE 22652, presented at the 1991 annual technology conference and exhibition, Dallas, 6-9 Oct 1991

Takahashi Sa, Haysdhi Y, Takahashi S, Yazawa N, Samra H (2003) "Characteristics and impact of asphaltene precipitation during $\mathrm{CO}_{2}$ injection in sandstone and carbonate cores: An Investigative Analysis Through Laboratory Tests and Compositional Simulator". In: SPE 84895, the SPE international improved oil recovery conference in Asia Pacific, Kula Lumpur, Malaysia, 20-21 Oct. 2003

Tiffin DF, Yeilig WF (1983) "Effects of mobile water on multiplecontact miscible gas displacements". SPE J 447-455

Wang FHL (1988) Effect of wettability alteration on water/oil relative permeability, dispersion, and flowable saturation in porous media. J SPERE 1988:617-628

Wolcott JM, Monger TG, Sassen R, Chinn EW (1989) “The Effects of $\mathrm{CO}_{2}$ flooding on reservoir mineral properties. In: SPE 18467, the SPE international symposium on oilfield chemistry, Houston, Texas, 8-10 Feb. 1989

Yang D, Gu Y (1994) "Visualization of interfacial interactions of crude oil- $\mathrm{CO}_{2}$ systems under reservoir conditions". In: SPE 89366, the SPE/DOE fourteenth symposium on improved oil recovery, Tulsa, 17-21 April 1994

Zekri AY, Almehaideb RA, Shedid SA (2006) "Displacement efficiency of supercritical $\mathrm{CO} 2$ flooding in tight carbonate rocks under immiscible and miscible conditions. In: SPE 98911, The SPE Europec/EAGE annual conference and exhibition, Vienna, Austria, 12-15 June 2006 